
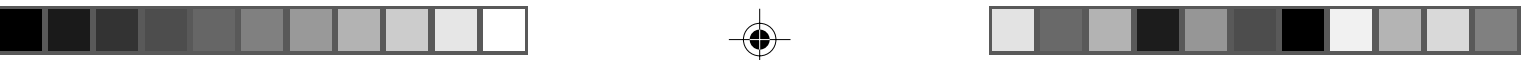

\title{
CATHRINE HASSE
}

\section{KULTUREL \\ VIDENSDIVERSITET}

\section{Om videnssystemers lukkede ontisk-epistemiske fantasier og nødvendigheden af vidensmægling}

Forestil dig en gruppe videnskabsfolk forsamlet til en konference. Det kunne være antropologer, biologer eller lingvister, men i dette tilfælde er det fysikere. De følger opmærksomt et PowerPoint-foredrag med billeder af rør, der ligger side om side, og ord som Higgs- og Z-partiklen. Forestil dig så, at vi kunne ,fryse“" situationen og begynde at udspørge hver enkelt person i rummet om, hvad han eller hun rent faktisk så på de billeder, der blev fremvist og forstod ved de ord, der blev sagt. Og forestil dig så, at det, de giver udtryk for at se og forstå, ikke er nøjagtigt det samme, men en lille smule forskelligt fra person til person, alt efter nationalt tilhørsforhold.

Det har ikke været muligt at udføre dette eksperiment in situ i min forskning blandt partikelfysikere, der arbejder på det samme projekt i Danmark og i Italien og jævnligt mødes til konferencer. I stedet har jeg opsøgt dem nogen tid efter konferencerne og bedt dem kommentere PowerPoint-slides af rør og udtalelser om Higgs-partikler. Disse kommentarer viser, som i ovenstående tænkte eksempel, at selvom fysikerne igen og igen mødes til de samme konferencer, opfatter de materielle objekter, der henviser til vigtige elementer i deres fælles projekt, forskelligt. Ikke vidt forskelligt, men forskelligt på måder, som det er vigtigt at udforske.

Det er nemlig ikke ligegyldigt, om italienske og danske fysikere forstår det samme ved PowerPoint-præsentationer, der er udgangspunkt for videre justeringer af nye rør og energitærskler. Fysikerne arbejder trods alt med en teknologi, der på grund af meget høje energier rummer en (om end lille) risiko for, at de i fællesskab kan frembringe et af de såkaldte ,sorte huller“, der, som det vises i science fiction-film, rummer energi nok til at opsluge såvel planeter som galakser (Calogero 2000).

Det er dog ikke sådan, at partikelfysikerne ikke forstår hinanden indbyrdes, men de gør det på måder, der kan forekomme helt uforståelige for lægfolk. De deler overvejende de samme fantasier om, hvad deres videnskab kan skabe af muligheder. I et demokratisk samfund er det heller ikke ligegyldigt, om vi lægfolk er helt eller kun delvist afskåret fra fysikernes fælles kognitive forestillings- og fantasiverden. Det er derfor nødvendigt, at vi begynder at stille nye spørgsmål til, hvad vi egentlig kan forstå af hinandens kognitive verdener, og hvad der konstituerer fælles forståelser i sådanne verdener. 

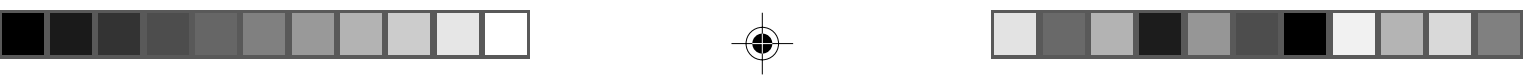

Spørgsmålet om, hvad der betinger, at mennesker opfatter verden forskelligt, har ikke været $\mathrm{i}$ høj kurs uden for antropologien. De mange muligheder for åben kommunikation på tværs af grænser - ikke mindst via internettet - har tværtimod skabt forestillinger om en ny uproblematisk udveksling af viden på tværs af klasseskel og landegrænser. Drømmen om et samfund, hvor mennesker frit udveksler og deler viden, kan få os til at tro, vi lever i et samfund uden kulturelle vidensdiversiteter.

Siden 1980'erne har samfundsvidenskabelige forskere ganske vist konstateret en øget opmærksomhed på det heterogene samfund - „forskellighed forener“ (Bauman 2001). Heterogenitetsforskning har været optaget af synlige forskelle som hudfarve og andre tydelige kropstegn. Fokus har været på udkantseksistenser, drags, hjemløse, køns- og etnicitetsdiversiteten (fx Hall 1996; Butler 1990; Crenshaw 1995; Bhabha 1994). Til gengæld har forskel på kognition, defineret i psykologien som tanker, underliggende formodninger, skemaer, ikke vakt den store interesse, hverken i antropologien eller samfundsvidenskaben i øvrigt. Det problematiske i at leve i en verden, hvor globaliseringen fremmer nye og langt mindre synlige kognitive forskelle mellem menneskers måder at forstå verden på, har ikke været genstand for samme voldsomme interesse som synlig kulturel forskel.

Vi går umiddelbart ud fra, at kultur betyder synlige forskelle - og at kultur dermed er noget vi kan se i form af forskellige hudfarver, køn, klædedragter osv. Det kultursyn, jeg her vil argumentere for, lægger vægt på, at kultur er et kognitivt fænomen - men ikke som noget essentielt, dvs. naturligt og synligt indlejret i den fysiske materialitet. Kultur er en position, man taler fra - noget man ser med, snarere end det, man ser. Derfor kræver det et eksternt perspektiv at se kultur (Hastrup 1992:41). Vi får som kulturforskere viden om andres kultur gennem dette eksterne perspektiv, og ligesom alle andre opdager vi kulturforskelle gennem,,implicit komparation“(Nader 1994; Hasse 2002:17). De erkendelser har i mit arbejde medført et fokus på de kulturpsykologiske processer, der transformerer den verden, vi perciperer, så vi oplever det ukendte som „kulturelt“. Hvad er det da, der skaber kulturelle forbløffelser? (Hastrup 1992). Et bud er „kulturelle læreprocesser““ (Hasse 2002:18). Kulturelle læreprocesser kan forstås som det, der skaber potentielle kulturforskelle i form af forskellige kognitive kulturelle modeller. ${ }^{1}$

Hvad er vidensdiversitet ifølge dette perspektiv, og hvordan kan vi forstå de mekanismer, der gør homogen kognition af en fælles verden vanskelig? I nyere kognitionsforskning gør man op med kognition som noget maskinelt (artificial intelligence), hvor krop og kognition kan tænkes adskilt. Viden, kognition og handling konstituerer hinanden (Núñez \& Freeman 2000). Viden kan antages at være distribueret i videnssystemer, der blandt andet betinger, hvorledes vi ser hinanden og vores samfund og forestiller os dets omformning. ${ }^{2}$ Viden er i dette perspektiv hverken at forstå som universalistisk eller relativistisk, men som viden i den tredje betydning: en ,incorporate“ praksisviden, der ofte har mere karakter af de daglige kropsritualer end en erkendt kognitiv viden (Watson-Verran 2001; Connerton 1989; Hastrup 1995). Videnssystemer har som videnstraditioner en rumlig dimension, der forbinder mennesker, steder og færdigheder (Turnbull 1997). Det er en kropsindlejret viden, der måske nok kan kaldes frem af forskere, men som i den daglige praksis fungerer som en lært fænomenologisk inkorporeret handleviden (Hasse 2002:208-9).

Distribution af denne form for handleviden afhænger af den enkeltes læreproces $i$ et større socialt praksisfællesskab og kan inden for et videnssystem føre til uenighed, diskussion, samarbejde og forhandlinger. ${ }^{3}$ Diskussioner mellem videnssystemer klares ikke med forhandlinger baseret på simple „oversættelser“, der søger at skabe lighed ved at 

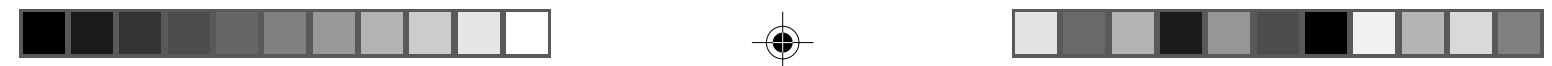

udjævne forskelle (Hastrup 1990). I den proces vil det partikulære forsvinde samtidig med videnssystemets særlige fremtidsfantasier og engagement. Fremtidsfantasier er knyttet til praksis i en hverdag, der praktiseres i et fælles offentligt rum. En „omgivelsernes totalitet", hvor jeg, vi og verden hører sammen (Zahavi 2001:115).

Som Polanyi har udtrykt det, er der to slags viden: den viden, der placeres i lærebøger, skrevne ord og tegn, og den uformulerede viden knyttet til hverdagshandlinger og relationer. Det er en anden slags viden - „tavs viden“ (Polanyi 1968:14). Normalt behøver vi ikke at „oversætte“ vores handleviden til andre. Det sker, når der opfindes nye praktikker, når nyankomne skal i lære i videnssystemet, eller når vi søger at kommunikere med andre videnssystemer - det, nogen ville kalde „,kulturmøder“. Her mødes mennesker fra forskellige videnssystemer, hvilket indebærer, at deres handleviden er forskellig. En eksplicit verbal „oversættelse“ af denne ellers tavse praksisdimension vil i sådanne situationer nemt få en politisk drejning, fordi der er et formål med at søge at sætte hverdagens mangfoldige og komplekse praksis på ord. Eksplicitte ytringer har altid et formål og altid modtagere.

Alligevel forlader vi os ofte umiddelbart og naivt på videnssystemets egne simple oversættelser i den implicitte tro, at når vi forstår den ekspliciterede viden, forstår vi også den handleviden, den bygger på. Hvor vi kan være mistroiske eller på vagt, når det gælder verbale ekspliciteringer af videnssystemer inden for områder, der allerede er diskursiveret som politiske sprængfelter (som etniske kulturmøder), er vi langt mindre på vagt, når der sker vidensoversættelser inden for, hvad vi opfatter som ,samme kultur“. ${ }^{4}$

Vidensdiversiteter er ikke synlige på samme måde som køn og etnicitet. Nogle menneskers kognitive kort over verden, opnået gennem handlinger i en hverdagspraksis, kan være både særligt magtfulde og særligt utilgængelige. Vi accepterer, at industrifolk, børsmæglere eller videnskabsmænd har en særlig indsigt, der er vanskelig at sætte spørgsmålstegn ved. Vi har hverken viden eller engagement til yderligere at gå i dialog med disse videnssystemer, men accepterer deres udlægninger af verden og tror måske endda at forstå den. Det er et problem for videnssamfundet (Lyotard 1979), der stiller nye krav til vores fælles diskussioner af hastige samfundsforandringer. Netop når vi tror at forstå ved at ,oversætte“ det ukendte til det kendte - er risikoen for misforståelse størst (Ardener 1989:165).

Videnssystemer er ikke lukkede, men det kræver mere end videnssystemets egne repræsentanters simple oversættelser af viden at forstå, hvad der driver videnssystemer fremad. Argumentet i denne artikel er, at et videnssystem grundlæggende er baseret på fælles engagement (Verran 1998). For at forstå tankegange i et videnssystem må vi have indsigt i de fantasier og forestillinger, der knytter sig til viden i et videnssystem. Netop fordi viden på overfladen forekommer tilgængelig og nem at udveksle, skjules vidensdiversiteter knyttet til handleviden og fremtidsfantasier og dermed vores forståelse af engagementer og fremtidsforestillinger knyttet til videnssystemer. Manglen på indsigt $\mathrm{i}$ vidensdiversiteter begrænser muligheden for at føre åbne ontisk-epistemiske politikker om fremtidens samfund. Højenergifysik er et eksempel på denne problematik.

\section{Vidensudfyldning}

På La Sapienza-universitetet i Rom har fysikerne som så mange andre steder et whiteboard på væggen på deres kontor. De hvide flader er dækket af streger, cirkler og tegn. Jeg tog 

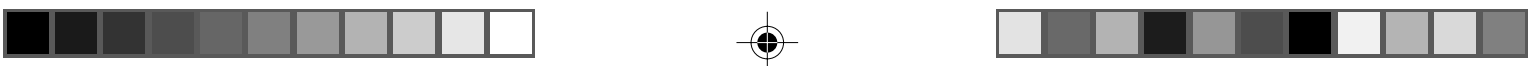

snapshot af disse overmalede tavler og viste dem til fysikere fra andre institutter og lægfolk. For en udenforstående ikke-fysiker er det vanskeligt at skabe mening i billederne på tavlerne. Fotografier af disse whiteboards er blevet kommenteret af folk, der ikke arbejder med fysik: „Det ligner en radio“, „, det er P-pladser“ eller ,de flade kasser er nok nogle huse, og så er stregerne veje, der går under dem“. En cirkel med stiplede linjer indeni kommenteres med: „Det ligner et ur“ eller „,det er nogen, der skal tage et stykke ud af en cirkel, men de ved ikke, om de kan“. De små tegn, en trekant + „t“, og Z’erne, ignoreres som regel.

Partikelfysikere fra Danmark, der også ser disse fotografier af deres italienske kollegers whiteboard for første gang, bruger derimod „„“ og Z'er til at identificere, hvad billedet forestiller. „Det, vi ser her, kunne godt være partikelspor, der går gennem nogle kamre. De to Z0'er henfalder til fire muoner - så det kunne være en Higgs, vi ser på her, “forklarer en fysiker. „Så er kasserne nok muon-detektor-kamre og de ligner vist vores 'strå' så meget, at jeg kan sige, at cirklen nok er et tværsnit af rørene fra kamrene. Det er fyldt med en gas - hvilket står heroppe, og så er delta [trekanten] ,t“ den tid, det tager for partiklen, at vandre ind gennem røret ind til den ladede tråd i midten, der giver signal om, at partiklen har ramt midten af røret. Fysikeren tilføjer: „Det er sjovt. Jeg vidste ikke, at deres [de italienske fysikeres] rør lignede vores strå så meget.“

Vi tillægger det vi ser en objektiv eksistens, uden for os selv og vores egen forståelseshorisont - og det, vi forstår, får ontologisk status (Hastrup 1999:167). Indimellem når vi iagttager et nyt billede (som det på whiteboarden) eller andre dele af vores omverden, får vi ikke tilstrækkelige forklaringer på, hvad det er, vi ser.

Jeg fortalte hverken lægpersoner eller fysikere, i hvilken kontekst tegnene var skabt. Fysikere og lægpersoner „oversætter“ tegnene på billederne, men lægpersoner er lidt mere i tvivl om betydningen end partikelfysikerne. Alligevel kan de sagtens få mening i tegnene ud fra tolkninger baseret på erfaringer fra deres egen hverdag. Selvom vi ikke har fysikerfaringer, har vi erfaringer med radioer, biler, veje og ure. Erfaringer sedimenteres gradvist som viden, og det er den viden, vi anvender til at deducere os frem til ny viden. Vi regner ud, hvad der er den mest sandsynlige tolkning ud fra det, vi allerede ved (D’Andrade 1995:126). Den manglende information fylder vi selv ud, så verden bliver genkendelig. Vi opfatter ved hjælp af, hvad der i kognitionsforskningen kaldes ,default values“ (manglende vurdering) - vi fylder ud med vores allerede etablerede viden, når det, vi sanser, ikke giver os de nødvendige oplysninger (D’Andrade 1992:52). Disse „,selvfølgelige udfyldninger“ danner baggrund, men skal også udfordres, for at vi lærer nyt: forklaret som „transformation“ i Vygotskys kulturhistoriske teori (fx Vygotsky 1978) eller ,adaption“ i Piagets konstruktionisme (fx Piaget 1967). Det, vi ved, betinger det, vi kan lære at vide. Da læring er forandring (Bateson 1972: 283), er det at lære noget nyt en langsommelig forandringsproces af det, vi ved, baseret på mødet mellem det, vi ved, og det vi kan lære at vide. De erfaringer, vi har gjort os, ændrer vores refleksionsgrundlag på den baggrund skaber vi nye betydninger og opmærksomhedsfelter (Hasse 2002:1302).

Selvom vi umiddelbart kan tolke os frem til noget, der giver en slags mening ud fra billedet på whiteboarden, vil det, vi forstår som lægpersoner, være meget langt fra forståelsen hos den fysiker, der har tegnet det. En væsentlig forskel på fysikerens og den forudsætningsløses tolkning af tegnene på tavlen er, at fysikeren har nogle særlige følelser, fantasier og et engagement investeret $\mathrm{i}$ tolkningerne. 

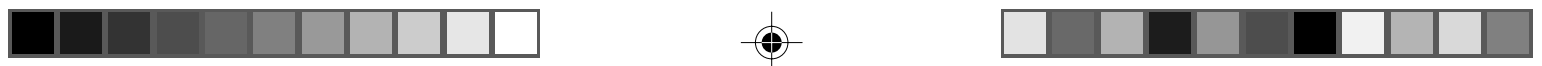

I en del år har jeg langsomt bevæget mig længere og længere ind i den fysiktankeverden, der kan give tegnene på whiteboarden engageret betydning for en fysiker. Jeg har, som Frederik Barth opfordrer til, studeret en videnstradition ved at tage udgangspunkt i de partikulære forbindelser, der skabes mellem en verden underlagt (hvad vi kan forstå som) naturlovene og de betydninger vi tillægger denne verden (Barth 1994). Jeg har fulgt de „loops“(

Jeg lærte i første omgang denne betydningsverden at kende ved at følge en gruppe første års fysikstuderende ind på et fysikinstitut i Danmark for at studere in- og eksklusionsprocesser i uddannelsessystemet og de læreprocesser, der angiver, hvad man skal lære for at blive anerkendt som en god fysikstuderende (Hasse 2003, 2002, 2002a). Siden har jeg gennem et års tid fulgt en gruppe højenergifysikforskere i Italien og Danmark på deres respektive universitetsinstitutter. De er alle tilknyttet det samme multinationalt organiserede fysikeksperimentet, ATLAS, der har hovedsæde på CERN (det europæiske partikelfysikcenter). På trods af forskellige nationaliteter er de medlemmer af samme videnssystem: partikelfysikkens hemmelige selskab.

\section{Pærernes hemmeligheder}

Fysik er en skopisk videnskab (baseret på visualitet) (Jay 1988), der lægger vægt på at visualisere og dermed tilsyneladende synliggøre. Der er ikke noget tydeligt fysisk tegn på hemmelig viden i fysikernes verden. Ingen lukkede døre, låste kister eller nysgerrige, der jages bort af vidensvogtere. Tværtimod. Alle udefrakommende kan få adgang til partikelfysikkens og ATLAS-eksperimentets grundlæggende formål, diskussioner og fremtidsforestillinger over internettet. De mange tusinde artikler om Higgs-bosoner og andre partikler, der skal undersøges i eksperimentet, kan findes i offentligt tilgængelige internationale tidsskrifter. Informationen er for så vidt fri. Ordene og tegnene er dog ikke nemmere at læse for lægfolk end tegnene på whiteboarden. Vi kan ikke stille noget op med den demokratisk distribuerede viden, hvis vi ikke har viden til at forstå den med. Der er ingen nem genvej mellem lægpersonens uvidenhed og partikelfysikerens viden.

På ATLAS-eksperimentets hjemmeside har informationsafdelingen gjort et ihærdigt arbejde for at få os til at forstå: To små runde kugler, der forestiller protoner, farer mod hinanden og støder sammen. Ved sammenstødet forvandles de to protoner til æbler, pærer og bananer. For partikelfysikeren, men ikke for mange andre, er der forbindelse mellem æbler, pærer og „radioerne“ på whiteboarden. De to visualiseringer er begge knyttet til højenergieksperimentet ATLAS og dermed forbundet med den 27 kilometer lange partikelaccelerator, Large Hadron Collider, der har hjemsted ved det europæiske partikelfysikcenter CERN i Schweiz. I eksempler med æbler og pærer forsøger fysikerne selv at oversætte deres eksperiment for lægfolk ved at trække på almindelige hverdagserfaringer. I begge tilfælde forsvinder fysikernes viden og engagement fra fremstillingen. Forsøg på oversættelser af partikler til pærer udjævner forskelle mellem lægperson og fysikerens videnssystemer. I processen fjernes alle de betydninger, der netop gør en forskel i fysikernes handlevidenssystem. Det genkendelige er genkendeligt, fordi det skjuler den egentlige uforståelighed og afstand mellem partikelfysikerens videnssystem og vores. Som Edwin Ardener udtrykker det, vil oversættelsen ikke bringe noget nyt, men være ,kortlagt igen efter vores eget hoved““- en oversættelse, der udligner alle forskelle (Ardener 1989:183). 

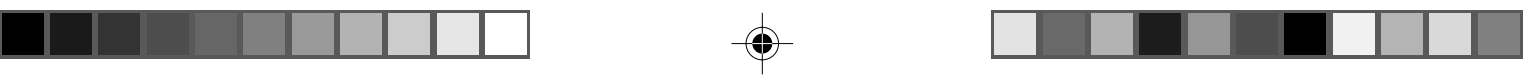

Ved at oversætte, hvad fysikerne selv betegner som ,jagten på Higgs-partiklen“, med frugt, får lægmanden fornemmelsen af, at fysikken i fremtiden vil skabe nye spændende muligheder for at frembringe materielle goder (æbler og pærer) ud af ingenting (protoner). Set fra ikke-fysikerens perspektiv behøver man ikke en mere engageret udspørgen til disse processer - og hvis man alligevel skulle finde på det, ville man hurtigt støde ind i de uforståelige tegn på whiteboarden og opgive engagementet.

Fysikforskerne er ikke interesserede i æbler og pærer, men i Z0'er og muoner. Fysikere er mennesker med et særligt engageret forhold til deres omverden - skal vi forstå denne tankeverden, må vi forstå mere end den viden, de deler. Det kræver indsigt i de fælles ontiskepistemiske fantasier og forestillinger, der konstituerer videnssystemer (Verran 1998).

\section{Videnspolitikker}

Er videnskabelig viden en særlig viden? Det spørgsmål har optaget det transdisciplinære felt Science and Technology Studies (STS) gennem mange år. Mange undersøgelser har argumenteret for, at videnskabelig viden ikke længere kan opfattes som en særligt privilegeret vidensform. Videnskabelige data konstrueres i en daglig praksis, der gennem sociale spil, teknologier, menneskeskabte normer, interesser og læreprocesser bliver skabt og forhandlet i videnskabssamfundet (Kuhn 1962; Merton 1973; Latour \& Woolgar 1986; Latour 1987; Shapin 1995). Denne indsigt i, hvorledes videnskabelig viden bliver til gennem lokale vidensproduktioner, har ført til en øget opmærksomhed på relationen mellem de materiel-semiotiske konstruktioner, der muliggør videnskabens fortsatte eksistens. Mange af undersøgelserne problematiserer forestillinger om en homogen værdifri objektivitetsforståelse som grundlag for de videnskabelige processer (Harding 1986; Haraway 1991). I stedet fokuseres på heterogeniteten i videnskabssamfundets konstruktioner. Feministisk og postkolonial videnskabsteori har eksempelvis peget på videnskaben som situeret (Haraway 1991), maskulint orienteret (Schiebinger 1989; Merchant 1990; Keller 1985) og desuden kønsmæssigt, etnisk og klassemæssigt skæv (Harding 1998) og baseret på forskellige videnskabsepistemologier (Knorr-Cetina 1999).

Disse mange praksisstudier i videnskabsforskningen har haft den uventede og ofte oversete konsekvens, at mange af de hidtidigt accepterede begrænsninger ved lokale videnssystemer, sammenlignet med videnskabens, er blevet opløst (Verran 1998:238). Videnskabsstudierne peger på heterogeniteten i disse „samlinger af viden“, og nu er tiden kommet, siger Helen Verran, til, at vi sætter os ud over heterogeniteten og ser på, hvad der konstituerer videnssystemer - herunder videnskabens.

Som Donna Haraway (1991) taler Verran om det materiel-semiotiske ved vores betegnelser og repræsentationer. Selvom materiel-semiotiske samlinger af begreber, teknologier m.v. fremstår som heterogene inden for et videnssystem, klumper de sig sammen og afslører deres grundlæggende homogene ontisk-epistemiske engagement, når der skal føres politik i forhold til andre videnssystemer. Vi kan ikke forstå sådanne politiker uden en opmærksomhed på ontisk-epistemiske ,fantasier“ knyttet til den handlepraksis, der skaber forestillingsevnen, der forbinder engagement, metaforer og billeddannelser med vores omgang med den materielle verden (Verran 1998).

Verran argumenterer for, at fantasier, troper og metaforer $\mathrm{i}$ den moderne vestlige tankegang samtidig er blevet brugt og fornægtet (op.cit.:250). I modsætning til det generelt 

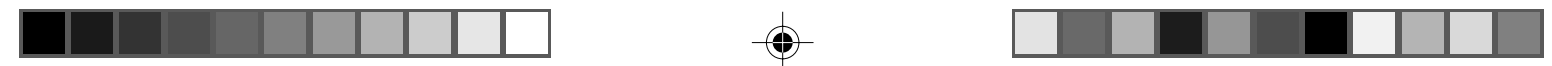

imaginære dækker hendes betegnelse ,imaginaries“ specifikke fantasier knyttet til videnssystemer. De materiel-semiotiske samlinger holdes (i hvert fald delvist) sammen som arbejdende enheder af en fælles forestilling: om de kategorier, gennem hvilke jorden bliver grundlæggende meningsfuld (ontisk engagement), og beretningen om tilblivelsen af denne meningsfuldhed (epistemisk engagement) (ibid.).

Bruno Latour har argumenteret for, at vi aldrig har været moderne. I vores daglige praksis kobler vi humane (fx fysikere) og non-humane (fx partikler) aktører, mens vi i vores tankeverden fortrænger disse sammenkoblinger og i stedet forestiller os, at de er adskilt (Latour 1993). Fantasien fortrænges på samme måde, hævder Verran, fra den vestlige tankeverden. Vi fortrænger dens store rolle, samtidig med at den betyder alt for vores ontisk-epistemiske politikker. I en diskussion af Kants fornuftsfilosofi påpeger Verran, at Kants forsøg på at forvise fantasien fra fornuften hviler på metaforen ,(fornuftens) Ø omgivet af (fantasiens) vilde bølger“. Fantasier er blevet ekskluderet fra vestlig kantiansk filosofi, fordi de opfattes som uforenelige med ræsonnement, logik og fornuft. Det har gjort os blinde for, at vores egen logik er baseret på metaforer og fortællinger (op.cit.:249). Ved at benægte fantasierne har vi gjort det muligt at fortrænge betegnelser som aktører.

Vi udspiller disse ontiske og epistemiske engagementer i diskussioner om ejerskab ved at handle ud fra de fælles forestillinger, der er grundlaget for et videnssystem - på trods af alle de indbyrdes diskussioner. Forestillinger er lokaliserede i praksis og mobiliseres gennem praksis. På den indirekte måde bidrager de til at konstituere ontisk-epistemiske videnssystemer.

Politikker mellem videnssystemer lader sig måske lettest identificere i forbindelse med deciderede kultursammenstød, men er ikke begrænset til sådanne åbenlyse situationer. Når to videnssystemer baseret på forskellige fantasier støder sammen - som to kulturer, der gensidigt spejler hinandens modsætninger (Nader 1994) - bliver vi opmærksomme på de forskellige grundlag, der konstituerer videnssystemers engagementer.

Verrans eget eksempel på et sammenstød mellem videnssystemer stammer fra Australien. I begyndelsen af 1990'erne afgjorde en højesteretsdom, at indfødte aboriginals adkomst til jord skulle anerkendes. De australske farmere, der lejede jorden af staten, skulle forhandle med de indfødte om retten til jorden. Afgørelsen er siden søgt omstødt. I processen har Verran identificeret, hvad hun kalder fremkomsten af en ny form for politik i Australien en politisk kamp mellem ontisk-epistemiske engagementer over, hvad der findes i verden, og hvem/hvad der kan vide det.

På den ene side står farmerne med deres vestlige videnssystem baseret på et kognitivt kort, der viser dem jorden som et på en gang tomt og ordnet sted. Konsekvensen er et landskab uden forandringer - et ensartet mønster, hvor ethvert punkt kan sammenlignes med det næste. Kortet, landskabet ses gennem, er tømt for fantasier og følelser. Farmernes kognitive kort er konstitueret ud fra en vestlig kvantifikationspraksis kombineret med en fornægtelse af de forestillinger, fortællinger, metaforer, der indgår i den performative frembringelse af kortet. Aboriginals har i modsætning til vesterlændinge ikke fortrængt eksistensen af fantasier, og de kender derfor landet på en helt anden måde og kan derfor ræsonnere på et andet grundlag end farmerne. I deres videnssystem er landet en række forbundne fokuspunkter (kaldet „hellige steder“ $\mathrm{i}$ den vestlige diskurs), og det er herigennem, at jorden får sin betydning. Skønt gruppen af aboriginals er heterogen, er videnssystemets grundlæggende konstituenter fælles. Betydningsskabelsen er forbundet med en logik, Verran opfatter som analog med vores vestlige talsystematik. Her tæller man 
ikke „på fingre“ (et materielt mønster), men via slægtskabsrelationer (et andet materielt mønster). Vores landkort opererer med neutrale opdelinger i ti gange ti, længder og bredder, $1,2,3,4,5,6,7,8,9,10$. Aboriginals har en anden praksis, der forbinder landet med slægten. Viden om landets fokuspunkter og forbindelserne mellem dem er indeholdt $i$ et stort korpus af historier, sange, danse og grafiske mønstre, og det generelle billede, der forbinder fortællinger, steder og forbindelser med dem, udgør en anden slags fælles kognitivt kort. Alle punkter på kortet er forskellige og som levet rum åbne for nye tolkninger. Den rekursive logik i begge systemer skaber begge betydning i landskabet.

Vestlige videnssystemer kan lære noget af de australske indfødtes videnssystemer, siger Verran, fordi aboriginals anerkender alt det, vi har fortrængt. Verran, der har arbejdet med at skabe et australsk undervisningssystem, der bedre tilgodeser en aboriginal tankegang, fungerer som mægler (cultural knowledge broker) mellem de to videnssystemer. Det er ikke umuligt at lære at tænke i en aboriginals forestillingsverden, skønt det tager tid. Der er ikke alene tale om forskellige ,tankestile“ (Fleck 1935), men om viden forbundet med praksis og situeret i denne praksis (Lave \& Wenger 1991). Modsætningen mellem ontologi og epistelomogi har altid været falsk, som Gregory Bateson konstaterede. Ontologi må forstås epistemologisk. At viden læres gennem deltagelse, er en konsekvens af denne erkendelse.

\section{Jagten på Higgs}

Det er heller ikke umuligt at lære at tænke som en partikelfysiker, skønt det tager tid. Fysikerne har jagtet den såkaldte Higgs-boson gennem mange eksperimenter siden 1964. Bortset fra nogle få antydninger af Higgs-partiklens tilstedeværelse i 1980'erne har man ikke fundet tilstrækkelige beviser for, at denne partikel eksisterer. Dermed har man heller ikke bevist, at den model for, hvad der skaber fast stof på jordkloden - i fysikken beskrevet gennem den såkaldte ,standardmodel“ - er korrekt.

Fysikeren er, i modsætning til de lægpersoner, der betragter billeder og tegn på whiteboarden, en engageret iagttager. Som John Dewey har bemærket, er interesser, mål, refleksion og formål uløseligt forbundet og bundet til forventninger om fremtiden. Deltageren er optaget af, hvad der foregår, fordi udfaldet af en begivenhed gør en forskel for ham. Derfor vil deltageren også handle, så udfaldet af det, der foregår, sikrer bedre, og undgår værre, konsekvenser, (Dewey 1916:124-5).

I de officielle beskrivelser af standardmodellen og Higgs er fysikernes fantasier og håb ikke nævnt. En partikel er som et punkt på de australske farmeres kort - uden historie og uden personligt engagement. I hverdagens praksis spiller fantasier, metaforer, troper og også håb en rolle som $i$ alle andre menneskers hverdagspraksisser. Udfaldet af et eksperiment har konsekvenser for fysikerne. Dels deres personlige ansættelsesforhold, men også deres forestilling om at tilhøre et bevaringsværdigt betydningsfuldt forskningsfelt. Skønt eksperimentet i den officielle retorik alene drejer sig om at få svar på, om Higgs-partiklen eksisterer, har fysikerne følelser, håb og fantasier investeret i svaret. Udfaldet gør en forskel.

For partikelfysikerne i ATLAS-projektet medfører det, at man nu nærmest frygter at få det klare nøgterne svar, eksperimentet lægger op til: Eksisterer Higgs? Det, fysikerne mere end noget andet frygter, er, at svaret ikke leder til nye spørgsmål, der kan berettige nye investeringer i partikelfysik i en overskuelig fremtid. 

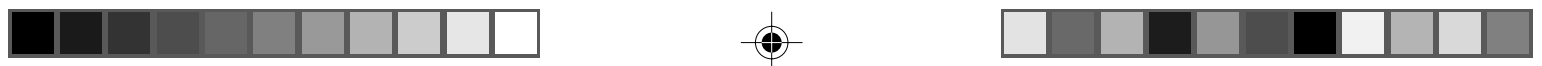

Officielt er formålet med eksperimentet selvfølgelig at finde Higgs, siger en fysiker. Uofficielt ønsker vi at kunne fortsætte med at holde vores viden om partikelfysikken i live ved at uddanne nye generationer gennem eksperimenter som ATLAS, men det bliver mindre og mindre attraktivt at være partikelfysiker. Vi nærmer os et punkt, hvor vi ikke kan få mere ud af denne type fysik. Alligevel fortsætter vi, fordi vi ønsker, at partikelfysikeksperimenterne skal fortsætte. Også selvom de er blevet alt for store og dyre som ATLAS.

En anden fysiker, Albert, der arbejder på de simulationer, der sammenholdt med eksperimentelle data kan vise om noget, der ligner en Higgs, dukker op i eksperimentet, ser meget dystert på fremtiden, hvis eksperimentets mest grundlæggende forudsigelser om Higgs fører til et ,ja“. På spørgsmålet om, hvad han ser som det vigtigste formål med projektet, svarer han, at formålet er at finde Higgs-partiklen, og tilføjer:

Jagten på Higgs kan åbne for forskellige scenarier [når eksperimentet først går i gang] af hvilke det værste er, at det kun er en partikel med en masse på ca. $130 \mathrm{GeV}$, som forudsagt i standardmodellen. Når den er fundet, må vi sige, at vi befinder os i et ørkenlandskab. Så er det slut. Ikke for fysik i det hele taget, men for denne type partikelfysik, ja, det tror jeg faktisk. [...] Man må håbe, vi finder en hel masse nye fænomener, så vi kan analysere nye ting. At lave alt det her arbejde bare for at bekræfte, hvad der er skrevet for 30 år, siden er ikke særligt spændende.

Holdningen er udbredt blandt næsten alle fysikere i mine interview. Håbet er, at man ikke finder det forventede. En anden fysiker, Dino, siger, at han af samme grund var meget skuffet, da man i 1994 fandt en anden forudsagt og vigtig partikel: topkvarken. De opdagelser, man gør i partikelfysikken i dag, er meget små, fordi de hele tiden bekræfter standardmodellen. Han havde håbet på overraskelser, der kunne gøre det spændende at være partikelfysiker i jagten på det ukendte.

Har engagementet og fantasier i partikelfysikernes videnssystem så relevans for lægfolk? Er det overhovedet noget, vi bør beskæftige os med? Andrew Pickering (1984) har vist, hvordan fysikernes data er konstruerede, og Karin Knorr-Cetina, hvordan fysikeres data skabes i ,epistemiske kulturer“ (1999). Studierne anfægter, at videnskaben kan hævde at have en særlig status som skaber af objektiv viden, der er gyldig uden for videnskabskulturen. Hvad der er lige så væsentligt i et samfundsperspektiv, er fysikernes fremtidsfantasier - herunder ønsker om at opretholde videnssystemet og konsekvenserne af dette engagement.

Jagten på Higgs finder ikke alene sin berettigelse i forhold til grundforskningsspørgsmålene: Hvad er masse og hvad er den materielle verdens inderste byggesten. Fysikernes engagement i ATLAS-eksperimentet er også et engagement i selve partikelforskningens overlevelse - også hvis man når den ørken, Albert omtaler.

Derfor har man også allerede planerne klar for det næste partikeleksperiment, der skal starte, uanset hvad man finder i ATLAS (og de andre eksperimenter tilknyttet CERNs programmer). I en tale i juni 2001 fastslog den daværende leder af CERN, Luciano Maiani, at målene nu er følgende: 1) at finde Higgs-bosonen, 2) at finde supersymmetriske partikler. Han fortsætter talen med spekulationer om en ,højenergigrænse“, der ligger uden for det nuværende eksperimentalanlægs kapacitet. Planerne er allerede i gang for at skabe en ny „lineær collider“. 


\section{Fremtidskollisioner}

Fremtidsforestillinger som disse er ikke alene knyttet til ønsket om svar, men til ønsket om partikelfysikkens overlevelse. For mange fysikere er det indlysende, at fremtiden skal gå mod højere energier og flere collidere. Det ligger indlejret i arbejdet med standardmodellens forudsigelser. Hvad der derimod ikke diskuteres hverken af fysikerne på CERN eller offentligt er, om det er de mange milliarder værd, som denne forskning koster. Endnu mindre diskuteres de risici, der er forbundet med projektet - eller måske endnu mere interessant - fysikernes fremtidsfantasier.

Forskning i samfundsforhold og humanistisk forskning har længe været under et politisk legitimationspres helt ned på enkeltforskerniveau. Her mangler forskerne fremtidsscenarier, der kan tale til politikernes visioner. Selvom partikelfysikkens lukkethed har været en beskyttende kappe om fysikforskningen, erfarer fysikerne i lighed med det øvrige universitetssystem et øget politisk pres. Flere fysikere bemærker i interviewene, at det nok er et spørgsmål om tid, før politikerne stiller spørgsmål om partikelforskningens relevans, og i USA har man for nogle år siden skrottet en ny collider til 80 milliarder kroner. Det har rystet mange fysikere. Alligevel mener de fleste ikke, at de endnu har været udsat for alvorligt politisk pres for at lukke CERN eller stoppe megaprojekter som ATLAS.

Det er interessant i forhold til det legitimationspres, forskningen ellers udsættes for ikke mindst de grene af den humanistiske forskning, der ligger nær almindelige borgeres egen forståelseshorisont. Mange vil umiddelbart mene, at de har viden og indsigt $i$ humanistiske og samfundsvidenskabelige spørgsmål. De færreste vil derimod hævde, at de forstår sig på partikelfysik. Fysikernes videnssystem er så tilpas uforståeligt, at man kan tillade oversættelser, der giver løfter om store samfundsmæssige gevinster af grundforskningen på længere sigt. Tænk, hvis vi i fremtiden vil kunne skabe æbler og pærer af protoner? Her er ingen ontisk-epistemiske politiske slåskampe som mellem de australske farmere og aboriginals. Fysikerne har deres videnssystem og engagement i fred - bortset fra enkelte små stik fra Science and Technology Studies (den internationale betegnelse for videnskabsstudier) og politikernes begyndende krav om rentabilitet og klare resultater.

Hvis videnssystemet blev involveret $i$ en offentlig debat, ville det ikke alene medføre de gustne økonomiske overvejelser om, hvorvidt partikelfysikken må koste 1 eller 2 milliarder kroner. Så ville vi, på linje med diskussioner om anden mere umiddelbar offentlig anvendelig forskning (såsom genetik og stamcelleforskning), diskutere forskningens risici. Vi lever i et risikosamfund (Bech 1994). Vores refleksioner over risici gælder kun risici knyttet til de videnssystemer, vi kender. De ukendte sættes ikke til debat. Derfor har man kun yderst begrænset offentligt diskuteret den meget lille sandsynlighed for, at fysikerne på CERN ved at skabe kollisioner med større og større energier kan komme til at skabe et såkaldt ,,sort hul“, der alene ved sin tyngdekraft risikerer at opsluge selve jordkloden (Calogero 2000). ${ }^{5}$ For fysikerne er det en lille risiko i forhold til det, de forestiller sig, de høje energier vil kunne fortælle os om massedannelse i universet. Når de ser PowerPointpræsentationer, der viser fremtidens potentiale, ser de løsninger på gamle gåder i fysikken - ikke nye menneskeskabte problemer. Disse fantasier er ,usynligt“ til stede i mange fysikeres perception af visuelle fremstillinger af ATLAS-projektet. Fordi de er usynlige, kræver det indsigt i fysikernes tankeverden at kunne se med.

En konflikt mellem fysikernes videnssystem og den viden, der generelt finder vej til medierne, ville også kunne sætte nyt fokus på fysikernes fremtidsfantasier. I modsætning 

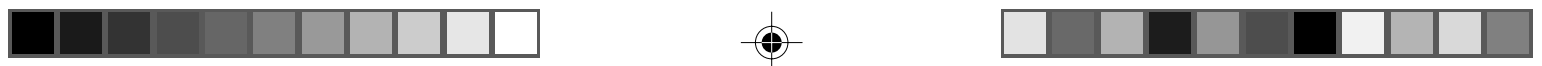

til mange andre menneskers fantasier har fysikernes fantasier reel mulighed for på ret kort sigt at føre til konkrete samfundsforandringer. Der er ikke kun tale om vidensdiversitet, men om en viden skabt i en praksis, der bærer fremtiden i sig og dermed skaber ,fremtidsfantasidiversiteter. Forestillingen om en mand på månen førte ikke bare rumraketter med sig, men forestillinger om, hvordan vi kan anvende rummet omkring os til satellitter, der kan sende informationer såvel som overvåge mennesker og maskiner. Der kunne måske være behov for andre fantasier, der udfordrer og problematiserer fysikernes fantasier. Hvilke konsekvenser får det for samfundsudviklingen, hvis standardmodellen faktisk bliver et redskab, vi kan handle efter? Det er endnu ikke diskuteret af andre end fysikerne selv i de sene nattetimer omkring de eksperimentelle dataanalyser, hvor der diskuteres science fiction-fantasier om at bygge nye verdener i ti dimensioner og skabe helt nye partikler.

Videnssystemets kognitive kort og vores mangel på erkendelse af fysikernes handleviden i den praktiske omgang med tilværelsens fænomener gør den til en „hemmelig“ viden, der alene forstås af de indviede, som vi alligevel tror at forstå ud fra vores eget videnssystem. Der vil være god brug for vidensmægling i et samfund, hvor skabelsen af ny viden medfører store forandringer. Verran kan fungere som en kulturel vidensmægler $\mathrm{i}$ de ontisk-epistemiske politikker omkring ejerskab til land i Australien, fordi konflikten allerede er synliggjort. En særlig opgave for fremtidens vidensmæglere bliver at opsøge hemmelige, men betydningsfulde videnssystemer og kalde deres ontisk-epistemiske fantasier frem til offentlig debat. Det gør en forskel, om mennesker tilhører de videnssystemer, der udvikler den nye viden, der gør en forskel for samfundsudvikling eller ej. Og om de mennesker, der ikke har viden til at skabe samfundsudvikling, kan diskutere med dem, der har. „Understanding is an imaginative event; it implies human agency“, skriver Kirsten Hastrup (1995:163). ${ }^{6}$ Det er tidskrævende og ikke helt ligetil at nå til forståelse af videnssystemers engagement, fantasier, forestillinger og fremtidshåb. Det kræver deltagelse i praksis at forstå andre menneskers kognitive verdener, så man bliver i stand til at kommunikere med dem på deres egne præmisser. Der er behov for antropologiske vidensmæglere, der lærer kognitiv betydning gennem deltagelse i praksis i, hvad der ellers opfattes som utilgængelige verdener. Erkendelse af behovet for vidensmæglere kunne betyde en efterspørgsel på forskere i videnssystemer, der ikke oversætter ved lighed, men ved forskel (Hastrup 1990). Som fremkaldere af politiske vidensdiversiteter og mæglere mellem videnssystemer vil denne forskning kunne skabe nye muligheder for politiske forhandlinger om samfundsudviklingen. Ellers vil viden, der er betydningsfuld for fremtidens samfundsudvikling, helt unddrage sig kritiske spørgsmål og diskussion.

\section{Noter}

1. Der findes en anselig litteratur om det antropologiske begreb „,kulturelle modeller“ - se eksempelvis D’Andrade og Strauss (1992).

2. Videnssystemet er at forstå som et analytisk begreb - en særlig afgrænsning af et analysefelt - der henter inspiration i Helen Verrans diskussioner som videnssystemer som inkorporeret praksis (Watson-Verran 2001; Verran 1998)

3. Videnssystemet minder om Ludwig Flecks videnskabelige ,tankekollektiver“, der blev videreudviklet 
af Thomas Kuhn til videnskabelige paradigmer (Fleck 1935; Kuhn 1962). Interne diskussioner og uenigheder finder sted inden for rammerne af det overordnede paradigme eller tankekollektiv. Hvor Thomas Kuhn udvikler ideen om tankekollektiver ved at pege på de læreprocesser, der skaber paradigmer, udvikler begrebet videnssystem fokus på den lokale ikke-erkendte handlepraksis $\mathrm{i}$ ethvert videnssystem. Der er nu ikke længere tale om det videnskabelige videnssystem, men det videnskabelige videnssystem, der sidestilles med andre ,indfødte“ videnssystemer (Watson-Verran \& Turnbull 1995).

4. Kultur kan som hverdagsbegreb anvendes diskursivt og politisk til at italesætte andre som „kulturelle“. Det videnskabelige kulturbegreb indeholdt i begrebet „kulturelle vidensdiversiteter“ angiver, at der altid skal redegøres for kultur som noget, der enten samler eller adskiller menneskelige fællesskaber (D’Andrade \& Strauss 1992). Kulturel viden skal således forstås som værende mere eller mindre fælles (Hasse 2002:208).

5. Nogle fysikere vil trække på smilebåndet af denne frygt, da man vurderer, at de sorte huller, man vil være i stand til at skabe på jorden, vil evaporere øjeblikkeligt. Andre fysikere mener ikke, at teorien om sorte huller er tilstrækkeligt belyst til, at muligheden for at skabe sorte huller kan udelukkes. Frygten for, at eksperimenter på CERN kan føre til sorte huller, blev blandt andet diskuteret af en række fysikere på italiensk tv, RAI III, søndag den 5. november $2000 \mathrm{kl} .23 \mathrm{i}$ et program med titlen „Potrebbe un esperimento distruggere la terra?“ (Kan et eksperiment tilintetgøre jorden?) ledet af studievært Milena Gabanelli (http://www.report.rai.it).

6. Det er et vanskeligt citat at oversætte, men her er et bud: „Forståelse er en forestillingsbegivenhed, der indebærer en aktiv medvirken."

\section{Litteratur}

Ardener, Edwin

1989 The Voice of Prophecy. Oxford: Basil Blackwell.

Barth, Fredrik

1994 A Personal View of Present Tasks and Priorities in Cultural and Social Anthropology.

I: R. Borofsky (ed.): Assessing Cultural Anthropology. New York: McGraw-Hill Inc.

Bateson, Gregory

1972 Steps to an Ecology of Mind. New York: Ballentine Books

Bauman, Zygmunt

2001 The Individualized Society. Cambridge: Polity Press.

Beck, Ulrich

1994 The Reinvention of Politics: Towards a Theory of Reflexive Modernization. I: U. Beck, A. Giddens \& S. Lash (eds.): Reflexive Modernization. Politics, Tradition and Aesthetics in the Modern Social Order. Cambridge: Polity Press.

Bhabha, Homi K

1994 The Location of Culture. London: Routledge

Butler, Judith

1990 Gender Trouble: Feminism and the Subversion of Identity. London: Routledge.

Calogero, Francesco

2000 Può un esperimento distruggere il pianeta terra? Sapere. Editione Dedalo, juli (4/229324-0)

Connerton, Paul

1989 How Societies Remember. Cambridge: Cambridge University Press

Crenshaw, Kimberlé Williams

1995 Mapping the Margins: Intersectionality, Identity Politics, and Violence Against Women of Color. I: K. Crenshaw et al. (eds.): Critical Race Theory. New York: The New Press. 
D'Andrade, Roy

1995 The Development of Cognitive Anthropology. Cambridge: Cambridge University Press.

1992 Cognitive Anthropology. I: T. Schwartz, G. White \& C. Lutz (eds.): New Directions in Psychological Anthropology. Cambridge: Cambridge University Press.

D’Andrade, Roy \& C. Strauss (eds.)

1992 Human Motives and Cultural Models. Cambridge: Cambridge University Press.

Dewey, John

1916 Democracy and Education. An Introduction to the Philosophy of Education. New York: The Free Press.

Fleck, Ludwig

1935 Entstehung und Entwicklung einer wissenschaftlichen Tatsache: Einführung in die Lehre vom Denkstil und vom Denkkollektiv. Basel: Benno Schwabe Co. (Genesis and Development of a Scientific Fact. The University of Chicago Press, 1979).

Hall, Stuart

1996 New Ethnicities. I: D. Morley \& Kuan-Hsing Cheb (eds.): Critical Dialogues in Cultural Studies. London: Routledge

Haraway, Donna

1991 Situated Knowledges: The Science Question in Feminism and the Privilege of Partial Perspective. I: D. Haraway: Simians, Cyborgs and Women: The Reinvention of Nature. New York: Routledge.

Harding Sandra

1986 The Science Question in Feminism. New York: Cornell University Press.

1998 Is Science Multicultural? Postcolonialisms, Feminisms, and Epistemologies. Bloomington: Indiana University Press.

Hasse, Cathrine

$2002 \quad$ Kultur i bevægelse - fra deltagerobservation til kulturanalyse. København: Forlaget Samfundslitteratur.

2002a Learning Physical Space. The Social Designation of Institutional Culture. FOLK 44:171-95.

2003 Kropstegns betydning i uddannelseskulturer. I: L. Højgaard \& D.M. Søndergaard (red.): Akademisk tilblivelse. København: Akademisk Forlag.

Hastrup, Kirsten

1990 The Ethnographic Present: A Reinvention. Cultural Anthropology 5(1):45-61

1992 Det antropologiske projekt om forbløffelse. København: Gyldendal.

1995 A Passage to Anthropology. Between Experience and Theory. London: Routledge.

1999 Viljen til viden. En humanistisk grundbog. København: Gyldendal.

Jay, Martin

1988 Scopic Regimes of Modernity. I: H. Forster (ed.): Vision and Visuality. Seattle: Bay.

Keller, Evelyn Fox

1985 Reflections on Gender and Science. New Haven: Yale University Press.

Knorr-Cetina, Karin

1999 Epistemic Cultures. Cambridge, MA: Harvard University Press.

Kuhn, Thomas S.

1962 The Structure of Scientific Revolutions. Chicago: The University of Chicago Press.

Latour, Bruno

1993 We Have Never Been Modern. London: Prentice Hall.

1987 Science in Action. How to Follow Scientists and Engineers through Society. Cambridge, MA: Harvard University Press. 

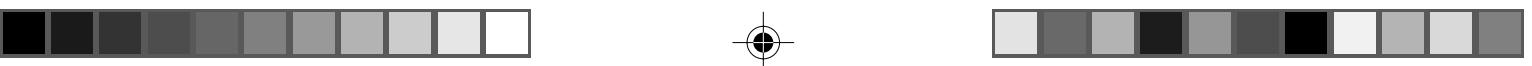

Latour, Bruno \& Steve Woolgar

1986 Laboratory Life: The Construction of Scientific Facts. Princeton: Princeton University Press.

Lave, Jean \& Etienne Wenger

1991 Situated Learning. Legitimate Peripheral Participation. Cambridge: Cambridge University Press.

Lyotard, Jean-François

1979 The Postmodern Condition. Manchester: Manchester University Press.

Merchant, Carolyn

1990 The Death of Nature: Women, Ecology and the Scientific Revolution. San Francisco: Harper.

Merton, Robert K.

1973 The Sociology of Science. Chicago: University of Chicago Press.

Nader, Laura

1994 Comparative Consiousness. I: R. Borofsky (ed.): Assessing Cultural Anthropology. New York: McGraw-Hill.

Núñez, Rafael \& Walter J. Freeman (eds.)

2000 Reclaiming Cognition: The Primacy of Action, Intention, and Emotion. Bowling Green, OH: Imprint Academic.

Piaget, Jean

1967 Six Psychological Studies. New York: Random House.

Pickering, Andrew

1984 Constructing Quarks: A Sociological History of Particle Physics. Edinburgh:

Edinburgh University Press.

Polanyi, Michael

1968 Understanding Ourselves. I: R.E. Ornstein (ed.): The Nature of Human

Consciousness. San Fransisco: W.H. Freeman and Compagny.

Schiebinger, Londa

1989 The Mind Has No Sex? Women in the Origins of Modern Science. Harvard: Harvard University Press.

Shapin, Stephen

1995 A Social History of Truth. Chicago: University of Chicago Press.

Turnbull, David

1997 Reframing Science and Other Local Knowledge Traditions. Futures 29(6):551-62.

Verran, Helen

1998 Re-imagining Land Ownership in Australia. Postcolonial Studies 1(2):237-54.

Vygotsky, Lev Semyonovich

1978 Mind in Society. The Development of Higher Psychological Processes. Cambridge,

MA: Harvard University Press.

Watson-Verran, Helen

2001 Science and an African Logic. Chicago: University of Chicago Press.

Watson-Verran, Helen \& David Turnbull

1995 Science and Other Indigenous Knowledge Systems. I: S. Jasanoff et al. (eds):

Handbook of Science and Technology Studies. London: Sage.

Zahavi, Dan

2001 Husserls fænomenologi. København: Gyldendal. 